Original research article

\title{
Evaluation of non-healing wounds
}

\author{
Adéla Holubová ${ }^{1,2}{ }^{*}$, Andrea Pokorná ${ }^{3}$ \\ ${ }^{1}$ University of South Bohemia in České Budějovice, Faculty of Health and Social Sciences, České Budějovice, Czech Republic \\ ${ }^{2}$ DiaPodi care s.r.o., Soběslav, Czech Republic \\ ${ }^{3}$ Masaryk University, Faculty of Medicine, Department of Nursing and Midwifery, Brno, Czech Republic
}

\begin{abstract}
Introduction: The treatment of patients with non-healing wounds requires a systematic approach, including a complete wound assessment and an accurate description of this assessment.

Methods: A cross-sectional retrospective study - content analysis of documentation from various localities of the Czech Republic. Using the cluster analysis method to find out if there are groups that differ in their approach to evaluating the parameters of non-healing wounds. 331 dossiers from 16 inpatient and outpatient care providers and social service providers were analysed.

Goals: The goal was to assess how non-healing wounds are evaluated and documented in clinical practice at selected health care and social care providers in the Czech Republic. To verify whether a clinical algorithm for evaluating non-healing wounds is available in clinical practice for selected providers and whether it is used.

Results: The resulting data can be divided into three separate clusters. Individual groups can be characterised as cluster 1 - "mixed documentation", which contains 280 content analyses; cluster 2 - "nursing documentation of wound healing consultants", which includes 45 content analyses; cluster 3 - "nursing documentation - pre-printed form”, which contains six content analyses. Cluster 2 shows more frequent use of objectification in the evaluation of wound parameters.

Conclusions: The research showed that evaluating the parameters of non-healing wounds is very inconsistent. The recommended procedure for assessing the condition of non-healing wounds is not adequately followed and accepted in clinical practice. We have verified that the presence of a wound healing consultant is related to the more frequent use of accurate scales to assess wounds.
\end{abstract}

Keywords: Accurate scale; Clinical algorithm; Evaluation; Non-healing wound; Wound healing consultant

\section{Introduction}

The epidemiological analysis monitoring the issue of non-healing wounds in the Czech Republic between 2007 and 2015 drew attention to the fact that an average of 70,609 patients with non-healing wounds out of a total of 2,219,898 patients were hospitalised annually (Pokorná et al., 2017). Good care of non-healing wounds requires an accurate description of the wound assessment (Gray, 2020). The evaluation of a non-healing wound is an essential step towards a well-designed, realistic treatment plan and subsequent treatment (Rose-McGuckin, 2019). Quality wound care requires accurate data collection in connection with wound evaluation; not only to design an appropriate wound care plan, but also to determine whether the wound care plan is cost-effective (Anghel et al., 2016).

The basis of wound management is the evaluation of the overall condition of the patient and the local assessment of the non-healing wound, including deeper structures, and on their basis, the choice of appropriate therapeutic strategies (Pokor- ná, 2014). Management of non-healing wounds requires regular evaluation of the healing process, using reliable evaluation tools sensitive to monitored changes (Hlinková et al., 2019).

The process of evaluating a non-healing wound is still very non-standardized in clinical practice in the Czech Republic. The result is inconsistent assessment in terms of evaluation quality and objectivity. Subsequently, ambiguities arise both in the transmission and sharing of information and also in ensuring the continuity of diagnostic and treatment processes (Pokorná and Leaper, 2015). There is a nationally accepted recommended procedure or algorithm for assessing the condition of non-healing wounds in clinical practice in the Czech Republic, but it is not adequately followed (Saibertová and Pokorná, 2016).

This study aimed to verify how non-healing wounds are evaluated and documented in clinical practice at selected health and social care providers in the Czech Republic. The goal was also to assess whether a clinical algorithm for non-healing wound assessment is available in clinical practice at selected providers and whether it is used.

\footnotetext{
* Corresponding author: Adéla Holubová, DiaPodi care s.r.o., Petra Voka 159, Soběslav, Czech Republic; e-mail: adela.holubova.33@seznam.cz http://doi.org/10.32725/kont.2021.040

Submitted: 2021-03-30 • Accepted: 2021-08-10 • Prepublished online: 2021-08-23 


\section{Materials and methods}

Data were obtained by primary research in a retrospective cross-sectional study through content analysis of closed medical documentation. The actual data collection was carried out between 2018 and 2019 at selected health service and social care providers in the Czech Republic.

This study focused on the monitored parameters of non-healing wounds. The parameters are used in documenting non-healing wounds. The study was carried out using a record sheet, which used three parameters: "yes" - the parameter was monitored, and "no" - the parameter was not monitored. Another option was the so-called "objectification". This meant that the documentation of the monitored parameters used the help of measurements, methods, or scales that allowed accurate evaluation of the wound. The analysed matrix consisted of information (variables) from the parameters related to assessing non-healing wounds and their recording in medical records to determine whether there are different groups of medical institutions that differ in their approach to the evaluation of non-healing wounds. The cluster analysis methodology was used for this purpose. The monitored identification variables were not used in the calculation of the resulting decomposition of the data matrix. Only the part of the data matrix containing columns related to meritorious issues was used to calculate the disintegration of the data matrix, i.e., to the type of documentation for wound evaluation, photo documentation, and general knowledge and basic monitored parameters of the wound. To identify potential groups, a procedure was used to calculate the similarity matrix based on the socalled 'Gower metric' and the subsequent application of a hierarchical agglomerative clustering algorithm. As a next step, an agglomerative hierarchical cluster analysis was performed, during which the so-called 'nearest neighbour' algorithm was used. The number of clusters was determined based on the data structure itself through differences in clustering levels. The so-called 'silhouette graph' was used to assess the quali- ty of the resulting decomposition and the homogeneity of the identified clusters. Basic statistical methods of one-stage and two-stage classification were also used to evaluate the data obtained by content analysis of the data. They were determined by dividing the absolute and relative frequencies.

\section{The characteristics of the research group}

The research group consisted of 16 health services and social care providers in the $\mathrm{Czech}$ Republic from four different regions (Prague, South Bohemian Region, Vysočina Region and Hradec Králové Region). Regardless of workplace type, the largest representation was from the South Bohemian Region $-62.5 \%$ $(n=10)$ of the facilities. The Prague Region representation was 25\% $(n=4)$ and 6.25\% $(n=1)$ from the Vysočina Region and the Hradec Králové Region (who were equally involved in the survey). The analysed documentation from outpatient care providers was $51.4 \%(n=170)$, from inpatient care $12 \%(n=$ $40)$, and $36.6 \%(n=121)$ out of $100 \%(n=331)$ from social care providers. The condition of providing care to persons with non-healing wounds and the existence of documentation for wound care was verified for all involved providers.

\section{Results}

Chart 1, i.e., dendrogram, captures the course of clustering, which was performed using the dissimilarity matrix using the nearest neighbour method. The process of clustering individual groups is evident when looking at the shape or course of the dendrogram. It is possible to divide the data into three clearly separated clusters. Identified clusters are indicated by red rectangles delimiting the boundaries of the identified clusters. The first cluster consists of $84.59 \%(n=280)$ of the analysed documents, the second cluster consists of $13.6 \%(n=45)$ and the third cluster contains only $1.81 \%(n=6)$ of the analysed documents (Table 1). This shows a significant disparity in representation. The detailed characteristics of the clusters are described below.

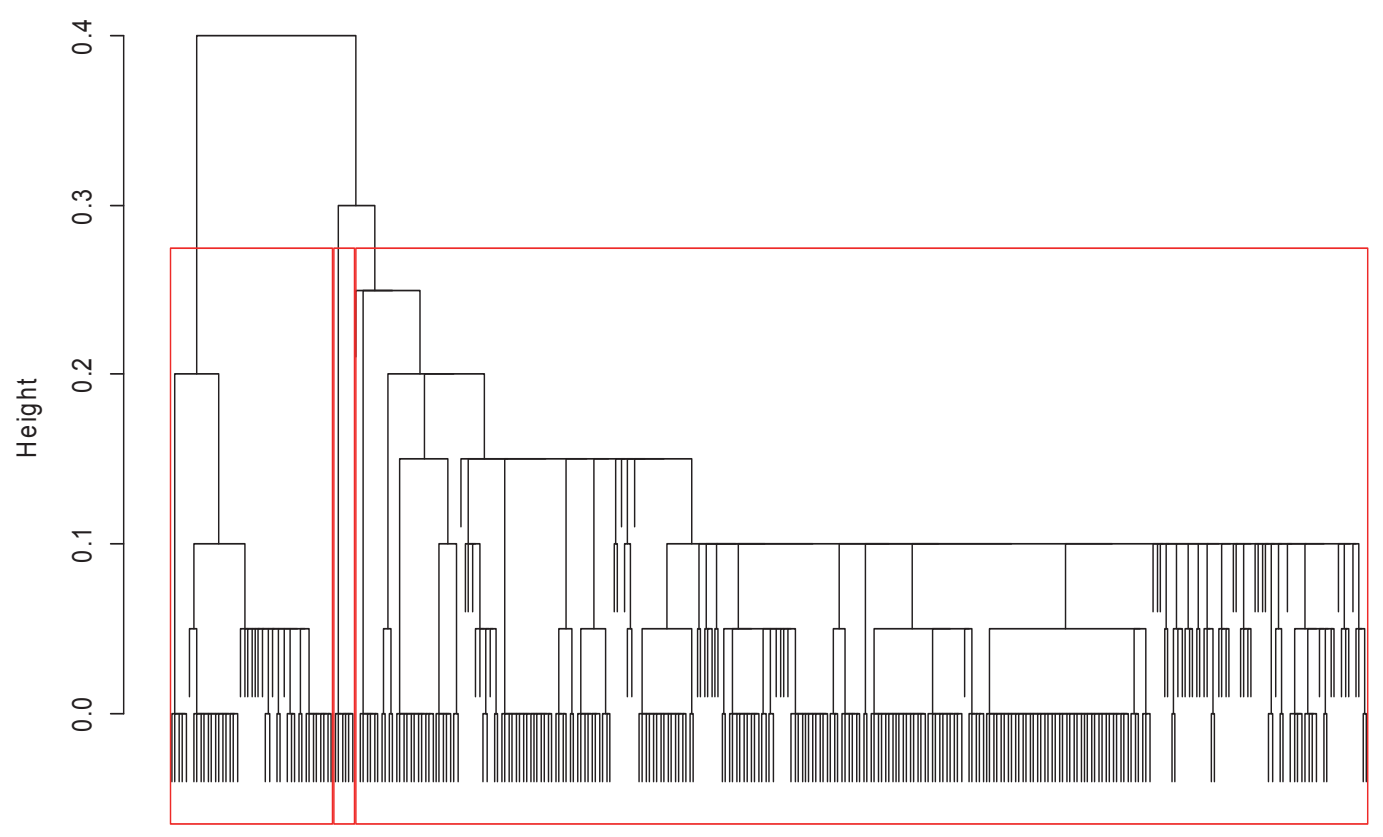

Chart 1. Final dendrogram of documentation analysis - three clusters 
Table 1. Clusters of analysed documentation and their percentage

\begin{tabular}{|c|c|c|c|c|c|c|c|c|} 
Documentation & \multicolumn{2}{|c|}{$\begin{array}{c}\text { Cluster 1 } \\
\text { "Mixed documentation" }\end{array}$} & $\begin{array}{c}\text { Cluster 2 } \\
\text { "Nursing documentation - } \\
\text { consultants" }\end{array}$ & $\begin{array}{c}\text { Cluster 3 } \\
\text { "Nursing documentation - } \\
\text { form" }\end{array}$ & $\begin{array}{c}\text { Total } \\
\end{array}$ \\
\hline$(n)$ & $(\%)$ & $(n)$ & $(\%)$ & $(n)$ & $(\%)$ & $(n)$ \\
\hline 280 & 84.59 & 45 & 13.60 & 6 & 1.81 & 331 & 100.00 \\
\hline
\end{tabular}

The final diagnostic Chart 2 shows that the resulting decomposition (average value is 0.48 ) shows an average to higher level of separation. We can assume that there are "natural, not artificial" groups of analysed documentation in the analysed documentation. From the shape of the silhouette plot, it is evident that the largest first cluster (Mixed documentation) shows a more significant heterogeneity, together with a certain part of the documentation that was probably not correctly classified (negative silhouette values). The compactness is slightly lower in the largest cluster compared to other clusters $\left(s_{1}=0.44\right)$. The second (Nursing documentation - consultants) and the third clusters (Nursing documentation - form) show a much greater degree of compactness than the first cluster. Thus, we can say that the medical documentation shows a much greater degree of agreement in the answers to the monitored parameters and questions than the documentation included in the first cluster. However, their cardinality is much smaller compared to the first cluster $\left(n_{2}=45 ; n_{3}=6\right)$.

The characteristics of clusters can be created through columnar absolute and relative frequencies for individual questions. The features of individual clusters are described in Ta- ble 2. Based on the hierarchical cluster analysis results, the individual groups/clusters can be characterised as follows: Cluster 1 can be called "mixed documentation". This cluster contains a total of 280 content analyses. Cluster 2 can be called the "nursing documentation of wound healing consultants", which includes 45 content analyses. Cluster 3 can be described as the cluster "nursing documentation - pre-printed form", which contains 6 content analyses. The pre-printed form, which includes general findings and basic monitored parameters for non-healing wounds, used cluster 3 in 100\% of cases $(n=6)$. The wound healing specialists did not evaluate the wounds according to the pre-printed form. They made entries in a flowing text which (as can be expected) corresponded to their knowledge regarding wound evaluation in $100 \%$ of cases $(n=45)$. Cluster 1 consisted of content analyses that were based on a pre-printed form $(10.7 \%, n=30)$. General nurses used the form, and records were written in flowing text without using a pre-printed form and predefined parameters. This type of documentation was used by doctors and nurses working for social care providers in $89.3 \%(n=250)$ cases.

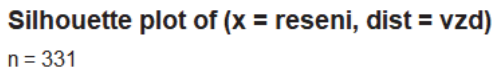

3 clusters $\mathrm{C}_{\mathrm{j}}$

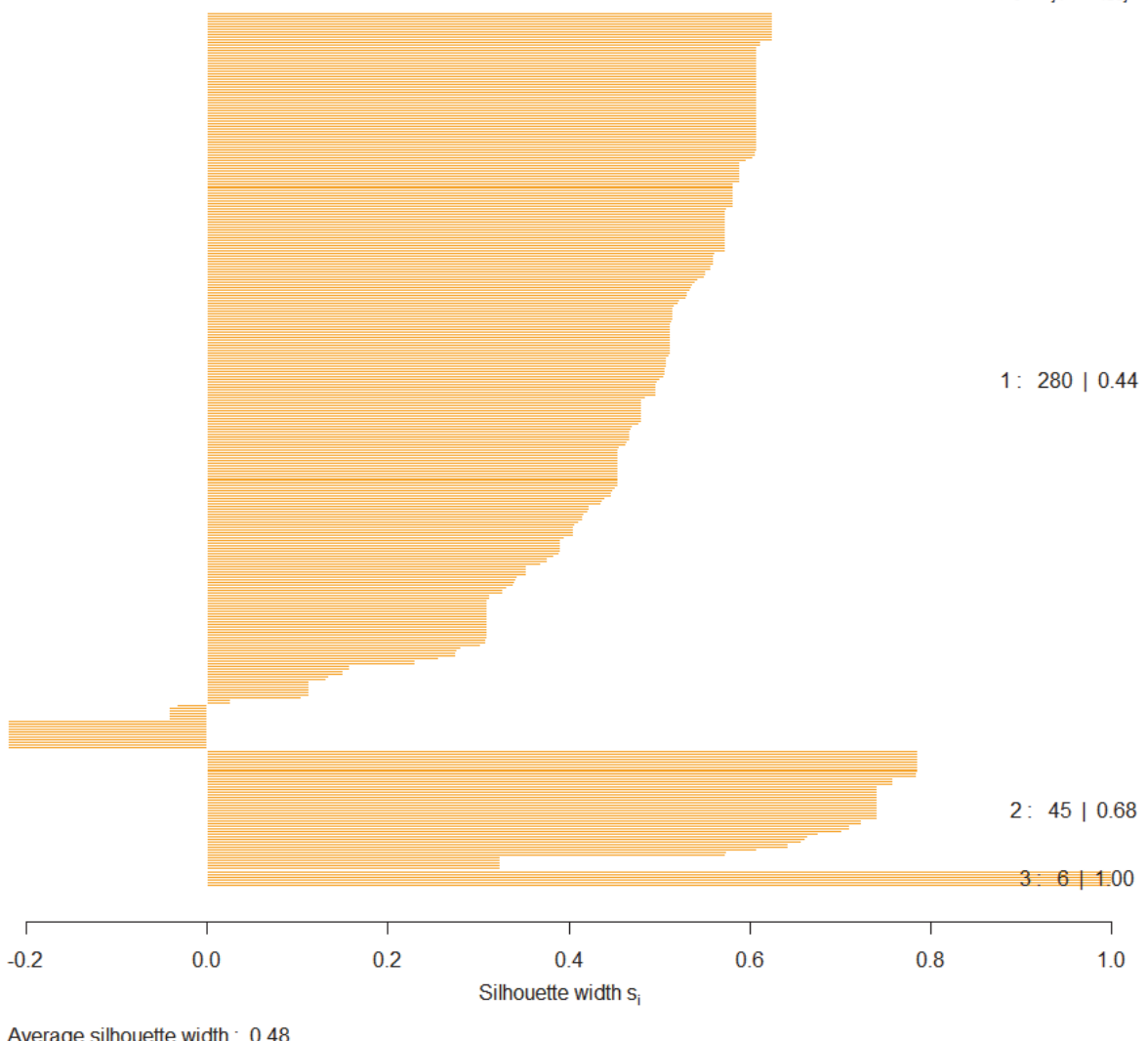

Average silhouette width : 0.48

Chart 2. Silhouette plot for decomposition into three 
Table 2. Profile of identified segments

\begin{tabular}{|c|c|c|c|c|c|c|c|}
\hline \multirow[t]{2}{*}{$\begin{array}{l}\text { Question/ } \\
\text { characteristics }\end{array}$} & \multirow[t]{2}{*}{ Level/category } & \multicolumn{2}{|c|}{$\begin{array}{c}\text { Cluster } 1 \\
\text { "Mixed documentation" }\end{array}$} & \multicolumn{2}{|c|}{$\begin{array}{c}\text { Cluster } 2 \\
\text { "Nursing documentation - } \\
\text { consultants" }\end{array}$} & \multicolumn{2}{|c|}{$\begin{array}{c}\text { Cluster } 3 \\
\text { "Nursing documentation } \\
\text { - form" }\end{array}$} \\
\hline & & (n) & (\%) & $(n)$ & (\%) & $(n)$ & (\%) \\
\hline Documentation & $\begin{array}{l}\text { doctor } \\
\text { nursing } \\
\text { nursing consultant }\end{array}$ & $\begin{array}{r}135 \\
145 \\
0\end{array}$ & $\begin{array}{r}48.20 \\
51.80 \\
0.00\end{array}$ & $\begin{array}{r}0 \\
0 \\
45\end{array}$ & $\begin{array}{r}0.00 \\
0.00 \\
100.00\end{array}$ & $\begin{array}{l}0 \\
6 \\
0\end{array}$ & $\begin{array}{r}0.00 \\
100.00 \\
0.00\end{array}$ \\
\hline Form & $\begin{array}{l}\text { yes } \\
\text { no }\end{array}$ & $\begin{array}{r}30 \\
250\end{array}$ & $\begin{array}{l}10.70 \\
89.30\end{array}$ & $\begin{array}{r}0 \\
45\end{array}$ & $\begin{array}{r}0.00 \\
100.00\end{array}$ & $\begin{array}{l}6 \\
0\end{array}$ & $\begin{array}{r}100.00 \\
0.00\end{array}$ \\
\hline Photodocumentation & $\begin{array}{l}\text { yes, part of documentation } \\
\text { yes, not part of documentation } \\
\text { no }\end{array}$ & $\begin{array}{r}0 \\
29 \\
251\end{array}$ & $\begin{array}{r}0.00 \\
10.40 \\
89.60\end{array}$ & $\begin{array}{r}0 \\
39 \\
6\end{array}$ & $\begin{array}{r}0.00 \\
86.70 \\
13.30\end{array}$ & $\begin{array}{l}6 \\
0 \\
0\end{array}$ & $\begin{array}{r}100.00 \\
0.00 \\
0.00\end{array}$ \\
\hline Nutrition & $\begin{array}{l}\text { yes } \\
\text { no } \\
\text { OBJ - BMI, NS }\end{array}$ & $\begin{array}{r}14 \\
266 \\
0\end{array}$ & $\begin{array}{r}5.00 \\
95.00 \\
0.00\end{array}$ & $\begin{array}{r}0 \\
15 \\
30\end{array}$ & $\begin{array}{r}0.00 \\
33.30 \\
66.70\end{array}$ & $\begin{array}{l}0 \\
6 \\
0\end{array}$ & $\begin{array}{r}0.00 \\
100.00 \\
0.00\end{array}$ \\
\hline Self-care & $\begin{array}{l}\text { yes } \\
\text { no } \\
\text { OBJ - ADL }\end{array}$ & $\begin{array}{r}13 \\
267 \\
0\end{array}$ & $\begin{array}{r}4.60 \\
95.40 \\
0.00\end{array}$ & $\begin{array}{r}3 \\
11 \\
31\end{array}$ & $\begin{array}{r}6.70 \\
24.40 \\
68.90\end{array}$ & $\begin{array}{l}0 \\
6 \\
0\end{array}$ & $\begin{array}{r}0.00 \\
100.00 \\
0.00\end{array}$ \\
\hline Type of wound & $\begin{array}{l}\text { yes } \\
\text { no }\end{array}$ & $\begin{array}{r}253 \\
27\end{array}$ & $\begin{array}{r}90.40 \\
9.60\end{array}$ & $\begin{array}{r}45 \\
0\end{array}$ & $\begin{array}{r}100.00 \\
0.00\end{array}$ & $\begin{array}{l}6 \\
0\end{array}$ & $\begin{array}{r}100.00 \\
0.00\end{array}$ \\
\hline Aetiology of wound & $\begin{array}{l}\text { yes } \\
\text { no }\end{array}$ & $\begin{array}{r}21 \\
259\end{array}$ & $\begin{array}{r}7.50 \\
92,50\end{array}$ & $\begin{array}{r}45 \\
0\end{array}$ & $\begin{array}{r}100.00 \\
0.00\end{array}$ & $\begin{array}{l}0 \\
6\end{array}$ & $\begin{array}{r}0.00 \\
100.00\end{array}$ \\
\hline Location & $\begin{array}{l}\text { yes } \\
\text { no } \\
\text { OBJ - Margoles map }\end{array}$ & $\begin{array}{r}253 \\
3 \\
24\end{array}$ & $\begin{array}{r}90.40 \\
1.10 \\
8.50\end{array}$ & $\begin{array}{r}45 \\
0 \\
0\end{array}$ & $\begin{array}{r}100.00 \\
0.00 \\
0.00\end{array}$ & $\begin{array}{l}0 \\
0 \\
6\end{array}$ & $\begin{array}{r}0.00 \\
0.00 \\
100.00\end{array}$ \\
\hline Size of wound & $\begin{array}{l}\text { yes "comparison" } \\
\text { no } \\
\text { OBJ }- \text { length } \times \text { width } \\
\text { OBJ }- \text { length } \times \text { width } \times \text { depth }\end{array}$ & $\begin{array}{r}12 \\
25 \\
165 \\
78\end{array}$ & $\begin{array}{r}4.30 \\
8.90 \\
58.90 \\
27.90\end{array}$ & $\begin{array}{r}0 \\
0 \\
0 \\
45\end{array}$ & $\begin{array}{r}0.00 \\
0.00 \\
0.00 \\
100.00\end{array}$ & $\begin{array}{l}0 \\
0 \\
0 \\
6\end{array}$ & $\begin{array}{r}0.00 \\
0.00 \\
0.00 \\
100.00\end{array}$ \\
\hline Measuring & $\begin{array}{l}\text { no } \\
\text { yes, without using aids for } \\
\quad \text { inexact measuring } \\
\text { OBJ - ruler } \\
\text { OBJ - ruler, tweezers } \\
\text { OBJ - ruler, probe }\end{array}$ & $\begin{array}{r}25 \\
12 \\
165 \\
50 \\
28\end{array}$ & $\begin{array}{r}32.40 \\
\\
1.10 \\
57.90 \\
1.10 \\
7.50\end{array}$ & $\begin{array}{r}0 \\
0 \\
0 \\
45\end{array}$ & $\begin{array}{r}0.00 \\
0.00 \\
0.00 \\
0.00 \\
100.00\end{array}$ & $\begin{array}{l}0 \\
0 \\
0 \\
6\end{array}$ & $\begin{array}{r}0.00 \\
0.00 \\
0.00 \\
0.00 \\
100.00\end{array}$ \\
\hline Wound bed & $\begin{array}{l}\text { yes } \\
\text { no } \\
\text { OBJ - WHC }\end{array}$ & $\begin{array}{r}179 \\
66 \\
35\end{array}$ & $\begin{array}{l}63.90 \\
23.60 \\
12.50\end{array}$ & $\begin{array}{r}0 \\
0 \\
45\end{array}$ & $\begin{array}{r}0.00 \\
0.00 \\
100.00\end{array}$ & $\begin{array}{l}0 \\
0 \\
6\end{array}$ & $\begin{array}{r}0.00 \\
0.00 \\
100.00\end{array}$ \\
\hline Exudate & $\begin{array}{l}\text { yes } \\
\text { no } \\
\text { OBJ - WEC } \\
\text { OBJ - WEC, WIC }\end{array}$ & $\begin{array}{r}139 \\
141 \\
0 \\
0\end{array}$ & $\begin{array}{r}49.60 \\
50.40 \\
0.00 \\
0.00\end{array}$ & $\begin{array}{r}0 \\
0 \\
5 \\
40\end{array}$ & $\begin{array}{r}0.00 \\
0.00 \\
11.10 \\
88.90\end{array}$ & $\begin{array}{l}0 \\
0 \\
0 \\
6\end{array}$ & $\begin{array}{r}0.00 \\
0.00 \\
0.00 \\
100.00\end{array}$ \\
\hline Wound edge & $\begin{array}{l}\text { yes } \\
\text { no }\end{array}$ & $\begin{array}{r}55 \\
225\end{array}$ & $\begin{array}{l}19.60 \\
80.40\end{array}$ & $\begin{array}{l}35 \\
10\end{array}$ & $\begin{array}{l}77.80 \\
22.20\end{array}$ & $\begin{array}{l}6 \\
0\end{array}$ & $\begin{array}{r}100.00 \\
0.00\end{array}$ \\
\hline Peri-wound skin & $\begin{array}{l}\text { yes } \\
\text { no }\end{array}$ & $\begin{array}{l}170 \\
110\end{array}$ & $\begin{array}{l}60.70 \\
39.30\end{array}$ & $\begin{array}{r}45 \\
0\end{array}$ & $\begin{array}{r}100.00 \\
0.00\end{array}$ & $\begin{array}{l}6 \\
0\end{array}$ & $\begin{array}{r}100.00 \\
0.00\end{array}$ \\
\hline Odour & $\begin{array}{l}\text { yes } \\
\text { no }\end{array}$ & $\begin{array}{r}39 \\
241\end{array}$ & $\begin{array}{l}13.90 \\
86.10\end{array}$ & $\begin{array}{r}45 \\
0\end{array}$ & $\begin{array}{r}100.00 \\
0.00\end{array}$ & $\begin{array}{l}6 \\
0\end{array}$ & $\begin{array}{r}100.00 \\
0.00\end{array}$ \\
\hline Signs of infection & $\begin{array}{l}\text { no } \\
\text { yes } \\
\text { OBJ - } 1 \\
\text { OBJ - 1, 2, } 4 \\
\text { OBJ - 1, 2, 3, } 4 \\
\text { OBJ - 1, } 2 \\
\text { OBJ - 1, 2, 3, 4, } 5 \\
\text { OBJ - 1, } 4\end{array}$ & $\begin{array}{r}166 \\
63 \\
14 \\
14 \\
4 \\
13 \\
1 \\
5\end{array}$ & $\begin{array}{r}59.30 \\
22.50 \\
5.00 \\
5.00 \\
1.40 \\
4.60 \\
0.40 \\
1.80\end{array}$ & $\begin{array}{r}0 \\
0 \\
0 \\
5 \\
19 \\
20 \\
1 \\
0\end{array}$ & $\begin{array}{r}0.00 \\
0.00 \\
0.00 \\
11.10 \\
42.20 \\
44.40 \\
2.20 \\
0.00\end{array}$ & $\begin{array}{l}0 \\
0 \\
0 \\
0 \\
6 \\
0 \\
0 \\
0\end{array}$ & $\begin{array}{r}0.00 \\
0.00 \\
0.00 \\
0.00 \\
100.00 \\
0.00 \\
0.00 \\
0.00\end{array}$ \\
\hline Pain & $\begin{array}{l}\text { yes } \\
\text { no } \\
\text { OBJ unidimensional scale }\end{array}$ & $\begin{array}{r}69 \\
211 \\
0\end{array}$ & $\begin{array}{r}24.60 \\
75.40 \\
0.00\end{array}$ & $\begin{array}{r}0 \\
0 \\
45\end{array}$ & $\begin{array}{r}0.00 \\
0.00 \\
100.00\end{array}$ & $\begin{array}{l}6 \\
0 \\
0\end{array}$ & $\begin{array}{r}100.00 \\
0.00 \\
0.00\end{array}$ \\
\hline
\end{tabular}


Table 2. (continued)

\begin{tabular}{|c|c|c|c|c|c|c|c|}
\hline \multirow[t]{2}{*}{$\begin{array}{l}\text { Question/ } \\
\text { characteristics }\end{array}$} & \multirow[t]{2}{*}{ Level/category } & \multicolumn{2}{|c|}{$\begin{array}{c}\text { Cluster } 1 \\
\text { "Mixed documentation" }\end{array}$} & \multicolumn{2}{|c|}{$\begin{array}{c}\text { Cluster } 2 \\
\text { "Nursing documentation - } \\
\text { consultants" }\end{array}$} & \multicolumn{2}{|c|}{$\begin{array}{c}\text { Cluster } 3 \\
\text { "Nursing documentation } \\
\text { - form" }\end{array}$} \\
\hline & & (n) & (\%) & (n) & (\%) & (n) & (\%) \\
\hline Treatment suggestion & $\begin{array}{l}\text { yes } \\
\text { no }\end{array}$ & $\begin{array}{r}280 \\
0\end{array}$ & $\begin{array}{r}100.00 \\
0.00\end{array}$ & $\begin{array}{r}45 \\
0\end{array}$ & $\begin{array}{r}100.00 \\
0.00\end{array}$ & $\begin{array}{l}6 \\
0\end{array}$ & $\begin{array}{r}100.00 \\
0.00\end{array}$ \\
\hline $\begin{array}{l}\text { Occurrence of a } \\
\text { clinical algorithm }\end{array}$ & $\begin{array}{l}\text { yes } \\
\text { no }\end{array}$ & $\begin{array}{r}0 \\
280\end{array}$ & $\begin{array}{r}0.00 \\
100.00\end{array}$ & $\begin{array}{r}40 \\
5\end{array}$ & $\begin{array}{l}88.90 \\
11.10\end{array}$ & $\begin{array}{l}0 \\
6\end{array}$ & $\begin{array}{r}0.00 \\
100.00\end{array}$ \\
\hline $\begin{array}{l}\text { Use of a clinical } \\
\text { algorithm }\end{array}$ & $\begin{array}{l}\text { yes } \\
\text { no }\end{array}$ & $\begin{array}{r}0 \\
280\end{array}$ & $\begin{array}{r}0.00 \\
100.00\end{array}$ & $\begin{array}{r}40 \\
5\end{array}$ & $\begin{array}{l}88.90 \\
11.10\end{array}$ & $\begin{array}{l}0 \\
6\end{array}$ & $\begin{array}{r}0.00 \\
100.00\end{array}$ \\
\hline
\end{tabular}

Abbreviations: ADL - Activities of Daily Living; BMI - Body Mass Index; NS - Nutritional Screening; OBJ - Objectification; WEC - Wound Exudate; WHC - Wound Healing Continuum; WIC - Wound Infection Continuum.

The clinical algorithm for evaluating non-healing wounds did not appear in $100 \%$ of the workplaces in clusters 1 and 3 (and therefore was not used). It appeared in cluster 2 and was used in $88.9 \%(n=40)$ of cases. Based on the results of the study, we can say that the clinical algorithm is more often used when the consultant is present, and this difference is statistically significant (Table 3).

Table 3. Use of the clinical algorithm for wound evaluation according to the presence of a consultant for wound healing

\begin{tabular}{|c|c|c|c|c|c|c|c|c|}
\hline \multirow{3}{*}{ Consultant } & \multicolumn{8}{|c|}{ Use of the clinical algorithm } \\
\hline & \multicolumn{2}{|c|}{ Frequency $(n)$} & \multirow{2}{*}{ Total } & \multicolumn{2}{|c|}{ Percentage (\%) } & \multirow{2}{*}{ Total } & \multicolumn{2}{|c|}{ Sign scheme } \\
\hline & no & yes & & no & yes & & no & yes \\
\hline No & 111 & 0 & 111 & 100.0 & 0.0 & 100.0 & +++ & --- \\
\hline Yes & 180 & 40 & 220 & 81.8 & 18.2 & 100.0 & --- & +++ \\
\hline Total & 291 & 40 & 331 & 87.9 & 12.1 & 100.0 & & \\
\hline
\end{tabular}

\section{Discussion}

In the implemented study, we assumed that the procedures in the assessment of wounds of health and social care providers differ. For the time being, there are not enough valid, scientifically verified source materials in the $C$ zech Republic describing the state of documenting non-healing wounds, apart from the works published by Pokorná and Leaper (2015) and Saibertová and Pokorná (2016), which are mentioned below. The presented results are part of an extensive survey, which included a questionnaire study. In this paper, we offer only the most exciting data from the content analysis of documentation.

Based on the obtained data, the analysed medical documentation can be divided into three groups. Cluster 1 was formed from the results of the content analysis of nursing documentation [52\% $(n=145)]$ and medical $[48 \%(n=135)]$ documentation.

The research results by Saibertová and Pokorná (2016) focused on evaluating non-healing wounds in 66 social care facilities. They verified that written medical documentation of wounds was kept in almost all workplaces. Our research results from 2018-2019 show that written medical documentation of non-healing wounds is performed at all workplaces providing social care.

Saibertová and Pokorná (2016) further state that the aetiology and age of the wound were among the most monitored parameters of wound evaluation. The results found in cluster
1, which included cluster analyses from mixed documentation, indicate that the aetiology of wounds was evaluated in only $8 \%(n=21)$ of cases out of 280 analysed documents. Another standard parameter reported in the research by Saibert and Pokorná (2016) was wound location and wound size. The authors mention evaluating these two parameters using objectification, where the location was verified in $42 \%$ and the size in $50 \%$ of the monitored care providers. Even without objective scales, evaluation of wound size was recorded in $50 \%$ and wound location in $57 \%$ of cases. The results of our research do not agree with wound location evaluation. The wound location was determined in $90 \%(n=253)$ of cases. In the area of wound size (measuring the length, width, and depth of the wound), the results of our study again differ. The wound size in the range length $\times$ width $\times$ depth was verified as recorded in only $28 \%(n=78)$ of cases.

We found other different results in the evaluation of the pain parameter. Sochor and Sláma (2015) state that pain has a sensory and emotional component, which is associated with anxiety, depression, aggression, feelings of endangerment, helplessness, hopelessness, and loss of motivation. All these factors lead to a deterioration in the quality of life. This is also confirmed by Vukelić and Jurić (2017), who state that pain significantly reduces the quality of life of a patient with a non-healing wound. Upton et al. (2012) add that stress during wound treatment increases cortisol levels, which negatively impacts wound healing. Nevertheless, the study found that pain was not one of the frequently monitored parameters. 
Palyzová (2007) defines procedural pain as time-limited somatic pain and mental discomfort. Such pain is brought about by a known cause and source related to diagnostic or therapeutic techniques. Edwads (2013) adds that procedural pain occurs during interventions and after a performance with different durations during these interventions (as well as after they end).

The results of research by Miertová and Ďurkechová (2012) prove that patients feel less pain before dressing, and the pain intensifies during dressing. Their research shows that there is a statistically significant difference between the perception of pain intensity before and during dressing ( $p=$ 0.0000). Ovšonková et al. (2017) add that effective procedural pain management provides comfort for patients during invasive procedures.

Jureníková et al. (2019) state that it is necessary to carry out a systematic evaluation of pain with a frequency corresponding to the individual needs of the patient for adequate pain treatment.

Dušičková et al. (2019) state that a quality measuring tool is necessary for the correct treatment of pain. Such a tool informs us about the intensity and propagation of pain concerning a specific activity. They add that the measuring tool allows nurses to evaluate the functionality of the provided care, understand the patient's feelings and, thus, helps to implement the nursing process.

Given (2010) states that healthcare professionals should always assume that any wound treatment may cause pain to the patient. Saibertová and Pokorná (2016) state that pain was assessed in $55 \%$ of workplaces.

Our research identified the monitored parameter pain in only $25 \%(n=40)$ of cases. Evaluation of pain using objective scales (unidimensional pain scale) was performed only within the documentation in cluster 2 in $100 \%(n=45)$ of cases. The pain intensity was evaluated, but the nature and possible occurrence of pain during dressing (procedural pain) were not assessed. In the documentation in cluster 3 , pain was also evaluated in $100 \%$ ( $n=6)$ of cases, but not with an objective scale or tool. Subjectivising adjectives were used, such as "there is no pain", "permanent pain", "occasional pain”, "acute or chronic pain", or "pain during dressing". In the analysed documentation in cluster 1 , the characteristics of pain were reported in $24.6 \%(n=69)$ of cases, but the records were in a very subjective form, such as "lesser pain" and "there is still pain". Koutná et al. (2015) state that questionnaires, scales, and different types of pain records are intended to help in the orientation of a patient's painful condition.

Koutná and Pokorná (2017) mention that the assessment of pain in individual medical workplaces of primary, secondary, and tertiary care is very different. Their study verified that the record of wound-related pain is part of the nursing documentation, but a common record of pain for other patients is also used.

Pokorná and Leaper (2015) published the results of extensive research involving 77 health care providers. They state that pain assessment is usually not part of the record of a non-healing wound. Pain is assessed and documented either in a particular form or in a routine patient record. However, this is not always the assessment of pain concerning a non-healing wound. Pain was most often assessed using a visual analogue scale (VAS). This parameter was consistent with the results of our study, in which we verified that in cluster 2, pain was assessed using a visual analogue scale.

The results of our study agree with the opinion of Zemanová and Zoubková (2012) and Dušičková (2019). They claim that practice mostly uses visual analogue scale. Pokorná et al. (2013) add that the use of VAS is appropriate due to its simplicity, comprehensibility, the possibility of repeated measurements and rapid evaluation.

Koutná and Pokorná (2017) state that VAS was used in $2 \%$ of cases, and the measurement group was a numerical scale, i.e., from $43 \%$ of all evaluation scales used by respondents. Benbow (2017) also describes the use of the VAS unidimensional scale and mentions that pain monitoring should include monitoring the nature, degree and frequency of pain and be monitored regularly using an objective scale. He adds that nursing staff should also consider verbal and nonverbal manifestations of pain (e.g., patients with dementia).

Photo documentation of non-healing wounds, which is part of patients' documentation, was found in the documentation in cluster 3 in $100 \%$ of cases $(n=6)$. Wound healing consultants used photo documentation of wounds, which was not part of the documentation and was stored on various media in $87 \%(n=39)$ of cases. In $13 \%(n=6)$ of cases, photo documentation was missing. Also, in cluster 1, photo documentation was not performed in $90 \%(n=251)$ of cases. Photo documentation of wounds was only performed in $10 \%(n=29)$ of cases, but this record was not part of the hospital information system. The analysis of the documents also revealed that the photo documentation of wounds was not performed regularly (with each dressing). It was not archived in printed form, it was stored on various media, and there was no standardised procedure for storing photo documentation of wounds. Pokorná and Leaper (2015) stated that photo documentation was implemented in most of the monitored workplaces [in $72 \%(n=68)$ of cases], but there were shortcomings. Photo documentation was taken without the patient's consent; the technical design did not meet the requirements for individual procedures, although Pokorná and Mrázová (2012) published recommendations on how to perform photo documentation of wounds in 2012. They recommended carrying out photo documentation during every dressing, maintaining anonymity, and allowing retrospective verification of relevant data. They also recommended providing sufficient lighting, taking photographs from the same angle and at the same distance from the wound, marking the wound with a metric number and the patient's initials, and stating whether the workplace requires consent to the patient's photo documentation.

Similar results regarding photo documentation were published by Saibertová and Pokorná (2016). They conducted their research with 66 social service providers and found that photo documentation was performed by $52 \%$ of providers, which is less common than in Pokorná and Leaper (2015). However, the quality of the photo documentation was insufficient. The technical design did not meet the requirements of individual procedures; photographs were taken from different distances and angles, were not performed with sufficient lighting or "over-lighting" due to the flash, or the pictures were of low quality. The photographs were stored anonymously and were not treated by the Personal Data Protection Act. Pokorná and Leaper (2015) add that a uniform methodology for taking photographic records of wounds and their appropriate storage is fundamental.

Haynes and Callagha (2015) argue that regular photo documentation of wounds provides a valuable visual record. Photo documentation is an essential component in evaluating non-healing wounds, as evidenced by the creation of a recommended procedure for wound photography - Guidelines for wound photography (NHS, 2017). 
Vyhlídalová et al. (2019) rightly point out that evaluating a wound from a photograph cannot be replaced by a clinical evaluation of a wound at a patient's bedside. However, from the point of view of monitoring the care process, it is an essential element.

Saibertová and Pokorná (2016) state that neither medical institution employees nor a wound-healing consultant found statistically significant differences in evaluating non-healing wounds. The results of our study are different. Evaluations of non-healing wounds performed by wound healing consultants included the most evaluated basic and specific wound parameters and more frequent use of objectifying tools and scales in evaluating both the local finding and the patient's overall condition. Regarding nutrition, the evaluation was verified by objectification in $67 \%$ of cases $(n=30)$, and in $69 \%(n=31)$ regarding self-care. Regarding wound size (length $\times$ width $\times$ depth), wound measurement using a ruler and probe and description using Wound Healing Continuum (WHC), the evaluation was verified in $100 \%(n=45)$ of cases. Saibertová and Pokorná (2016) state that the description of wound bottom using WHC was verified in $36.4 \%$ of social care providers. The wound bottom was described as black, yellow, red, or pink, and only two providers verified colour transitions, such as black and yellow.

Pokorná and Leaper (2015) verified the objective use of WHC in $49.5 \%$ of workplaces. They agree with the results of research by Seibertová and Pokorná (2016). They add that only primary colours were recorded, and the transitional type of wound bottom was evaluated at only two workplaces. Other parameters were no longer assessed in $100 \%$ of cases. Still, a higher incidence was verified for objective evaluation of exudate using Wound Infection Continuum (WIC) and Wound Exudate Continuum (WEC) in $89 \%(n=40)$ of cases. Pokorná and Leaper (2015) verified the evaluation of exudates according to the colour scale, where the exudate was described as serous, serosanguinous, or purulent. $15 \%(n=14)$ of workplaces used inaccurate terminology in evaluations (e.g., yellow, green, grey).

In a study on social service providers, Saibertová and Pokorná (2016) confirmed the previous findings of Pokorná and Leaper (2015) implemented in the facilities of health service providers. The authors verified the evaluation of the exudate character by describing serous, serosanguinous, or purulent evaluation, as well as the evaluation of the exudate by colour. They state that nurses evaluated exudate in association with coverage in only 10 cases out of 66 evaluated social service facilities.

The frequency in our study occurred in $44 \%(n=20)$ of cases regarding the objective assessment of the parameters of signs of infection. From a factual point of view, we should emphasise that the consultants did not fill in the pre-printed form. Still, their record was a fluent text that corresponded with their knowledge regarding evaluating monitored wound parameters. Saibertová and Pokorná (2016) state that evaluating non-healing wounds in social service facilities is insufficient. Our research results show that the content of the evaluation of non-healing wounds in the monitored facilities providing social care is inadequate.

The clinical algorithm for evaluating non-healing wounds did not occur in clusters 1 and 3 and therefore was not used either. It appeared in cluster 2 and was used in $89 \%(n=40)$ of cases. Based on the survey, it was verified that the clinical algorithm is used more often if a consultant is present.

Pokorná (2014) states that finding inconsistencies in the procedures for evaluating the parameters of non-healing wounds served as the base for creating an algorithm for assessing non-healing wounds. It was reviewed by members of the Czech Society for Wound Treatment. This document was primarily intended for non-medical healthcare professionals, but (in the sense of interconnected care) it was also designed for physicians and other members of multidisciplinary teams. It aimed to clearly define the lege artis procedure and insurmountable minimum care (Pokorná and Stryja 2014).

The results of our research show that the clinical algorithm for evaluating non-healing wounds did not occur in clusters 1 and 3 in $100 \%(n=280)$ of cases and was not used. It appeared in cluster 2 and was used in $89 \%(n=40)$ of cases. The use of the clinical algorithm for evaluating non-healing wounds varied by the category of the health service provider (faculty/ non-faculty). The use of the clinical algorithm was verified only in non-faculty health service providers (in $12 \%(n=14)$ ). The statistical analysis results ( $\chi^{2}$ test) show that the use of a clinical algorithm for evaluating non-healing wounds differs by the category of the health service provider. The use of the clinical algorithm was significantly more frequent in non-faculty health service providers $(p=0.038)$. The clinical algorithm is more often used when the wound-healing consultant is present. This difference is statistically significant $(p<0.001)$.

The results of the performed tests show that the use of a clinical algorithm for evaluating non-healing wounds differs by type of care. The clinical algorithm is more often used in outpatient facilities. This difference is statistically significant $(p<0.001)$. We should emphasise that the result may be affected by the number of analysed documents because the highest number of documents was from outpatient health care providers $[51.4 \%(n=170)]$. The number of analysed documents from inpatient care was $12 \%(n=40)$, and $36.6 \%(n=121)$ from social service providers. The total number of analysed documents was 331.

In clinical practice, evaluating non-healing wounds often depends on the evaluation of several different evaluators. Thus, a reliable tool guarantees its stability (Dušek et al., 2011). Using appropriate tools must be in line with scientific knowledge. No medical field can imagine providing health services and quality nursing care without research (Búruilová and Pokorná, 2017).

\section{Conclusions}

We confirmed that the scope of evaluating parameters of non-healing wounds differs in clinical practice and is very inconsistent. We found that the analysed cluster 1 , which included the documentation of doctors, nurses and social care providers, was of the lowest quality. Objectification of data by using objective scales was almost non-existent in cluster 1 . The documentation in cluster 2 was processed by wound healing consultants. It contained objective scales and evaluated parameters in the most significant number. The consultants did not fill in any pre-printed forms, but their record was a fluent text which corresponded to their knowledge regarding evaluating monitored wound parameters. Cluster 3 included nursing documentation on pre-printed forms. This documentation included objective scales, and photo documentation was an integral part of the patient's medical documentation. The results show that the work of the consultant has a positive effect, not only on the objective wound evaluation, but also on the provision of care. The results pointed to the necessity of standardising wound evaluation procedures. The study also showed that the recommended procedure or algorithm for assessing 
the condition of non-healing wounds was not adequately followed and accepted in clinical practice, which results in inconsistencies in wound assessment. The availability and use of an algorithm for evaluating non-healing wounds was confirmed by only one health care provider and a wound healing consultant was present.

\section{Conflict of interests}

The authors declare no potential conflict of interests with respect to the research, authorship, and/or publication of this article.

\section{Acknowledgements}

We would like to thank all the nurses for their support and collaboration in filling out the questionnaire.

\section{Ethics and consent}

The relevant committees approved the study (the approval does not include the IRB number from the ethics committee, which is common practice in the hospitals involved). The data have been used in an anonymous manner and presented at the group level only.

\section{Hodnocení nehojících se ran}

\section{Souhrn}

Úvod: Léčba pacientů s nehojícími se ranami vyžaduje systematický přístup, který by měl zahrnovat kompletní posouzení rány a objektivní popis hodnocení rány.

Metodika: Průřezová retrospektivní studie - obsahová analýza dokumentace z různých lokalit České republiky. S využitím metody shlukové analýzy zjistit, jestli existují různé skupiny, které se liší svým přístupem k hodnocení parametrů nehojících se ran. Analyzováno bylo 331 dokumentací od 16 poskytovatelů lůžkové a ambulantní péče a u poskytovatelů sociálních služeb.

Cíl: Cílem bylo posoudit, jakým způsobem jsou hodnoceny a dokumentovány nehojící se rány v klinické praxi u vybraných poskytovatelů zdravotních služeb a u poskytovatelů sociální péče v České republice. Ověřit, zda je v klinické praxi u vybraných poskytovatelů k dispozici klinický algoritmus pro hodnocení nehojící se rány a zda je využíván.

Výsledky: Výsledná data lze rozdělit do tří separovaných shluků. Jednotlivé skupiny lze charakterizovat jako shluk 1 „smíšená dokumentace“, tento shluk obsahuje celkem 280 obsahových analýz, shluk 2 „ošetřovatelská dokumentace konzultantek pro hojení ran“, který obsahuje 45 obsahových analýz, a shluk 3 „ošetřovatelská dokumentace - předtištěný formulář", jenž obsahuje 6 obsahových analýz. Shluk 2 vykazuje častější používání objektivizace při hodnocení parametrů ran.

Závěr: Průzkum prokázal, že proces hodnocení parametrů nehojící se rány je velmi nesourodý, že není v klinické praxi řádně dodržován a akceptován doporučený postup pro posuzování stavu nehojících se ran. Ověřili jsme, že př́itomnost konzultantky pro hojení ran souvisí s častějším používáním objektivních škál k hodnocení ran.

Klíčová slova: hodnocení; klinický algoritmus; konzultantka hojení ran; nehojící se rána; objektivní škála

\section{References}

1. Anghel EL, Kumar A, Bigham TE, Maselli KM, Steinberg JS, Evans KK, et al. (2016) The reliability of novel mobile 3-dimensional wound management device. Wounds 28(11): 379-386.

2. Benbow M (2017). Assessment, prevention and management of skin tears. Nurs Older People 29(4): 31-39. DOI: 10.7748/ nop.2017.e904.

3. Búřilová P, Pokorná A (2017). Role výzkumné sestry v klinických hodnoceních. Kontakt 19(3): 177-182. DOI: 10.1016/j. kontakt.2017.05.002.

4. Dušek L, Pavlík T, Jarkovský J, Koptíková J (2011). Analýza dat v neurologii XXIX. - Spolehlivost (reliabilita) klinických testů. Cesk Slov Neurol N 74/107(5): 594-599.

5. Dušičková T, Toumová K, Tóthová V (2019). Porovnání nástrojů sloužících $\mathrm{k}$ hodnocení bolesti $\mathrm{v}$ předškolním a mladším školním věku v České republice a zahraničí. Pediatr Praxi 20(4): 261-264. DOI: 10.36290/ped.2019.053.

6. Edwards J (2013). Dealing with wounds-related pain at dressing change. J Clin Nurs 27(4): 36-42.

7. Given J (2010). Management of procedural pain in adult patients. Nurs Stand 25(14): 35-40. DOI: 10.7748/ ns2010.12.25.14.35.c8153.

8. Gray L (2020). Standardising accurate wound assessment and documentation. J Comm Nurs 34(1): 14-14.

9. Haynes JS, Callagha, R (2015). Wound Assessment and Management Guideline CL-078. Worcestershire Health and Care NHS Trust, $35 \mathrm{p}$.
10. Hlinková E, Nemcová J, Hul'o E, et al. (2019). Management chronických ran. Praha: Grada, 232 p.

11. Juřeníková P, Novotný T, Staffa R, Krejčí M (2019). Hodnocení bolesti operačních ran po angiochirurgických výkonech. Cesk Slov Neurol N 82(Suppl. 1): 44-46. DOI: 10.14735/ amcsnn2019S44.

12. Koutná M, Pokorná A (2017). Znalosti a zkušenosti sester konzultantek pro hojení ran v managementu bolesti u nemocného s ránou. Bolest 20(1): 32-41.

13. Koutná M, Ulrych O, et al. (2015). Manuál hojení ran v intenzivní péči. Praha: Galén, 200 p.

14. Miertová M, Durkechová D (2012). Niektoré z problémov pacienta s ulcus cruris venosum. Ošetrovatel'stvo 2(3): 113-119.

15. NHS - National Health Services (2017). Northamptonshire Healthcare: Guidelines for wound photography.

16. Ovšonková A, Hudecová K, Miertová M, Čáp J. (2017). Problematika procedurálnej bolesti u detí z pohl'adu sestier. Kontakt 19(3): 183-189. DOI: 10.1016/j.kontakt.2017.06.004.

17. Palyzová $\mathrm{D}$ (2007). Procedurální bolest v dětském věku. Bolest 10(4): 197-204.

18. Pokorná A (2014). Proces hodnocení nehojící se rány v ČR průřezová studie. Hojení ran 8(1): 7.

19. Pokorná A, Leaper D (2015). Assessment and documentation of non-healing, chronic wounds in inpatient health care facilities in the Czech Republic: an evaluation study. Int Wound J 12(2): 224-231. DOI: 10.1111/iwj.12372.

20. Pokorná A, Mrázová A (2012). Kompendium hojení ran pro sestry. Praha: Grada, 192 p.

21. Pokorná A, Stryja J (2014). Klinický algoritmus hodnocení nehojící se rány - implementace $\mathrm{v}$ praxi pohledem sestry a lékaře. Hojení ran 8(1): 7-8. 
22. Pokorná A, et al. (2013). Ošetřovatelství v geriatrii: hodnoticí nástroje. Praha: Grada, 202 p.

23. Pokorná $A$, Benešová $K$, Mužík J, Jarkovský J, Dušek L (2017). Data Sources for Monitorirng of Non-healing Wounds in a National Heal Information System - Epidemiology of Non-healing Wounds Analysis of the National Register of Hospitalized Patients in 2007-2015. Cesk Slov Neurol 80 (Suppl. 1): 8-17. DOI: 10.14735/amcsnn2017S8.

24. Rose-McGuckin K (2019). IMI National Guidelines, A Guide to Good Practice. Wound Management Photography.

25. Saibertová S, Pokorná A (2016). Evaluation of the assessment and documentation of chronic wounds in residential social care in the Czech Republic. J Wound Care 25(11): 662-669. DOI: 10.12968/jowc.2016.25.11.662.

26. Sochor M, Sláma O (2015). Management chronické a akutní bolesti u pacientů s nádorovými chorobami. Klin Onkol 2(2): 94-98. DOI: 10.14735/amko201594.
27. Upton D, Solowiej K, Hender C, Woodyatt KY (2012). Stress and pain associated with dressing change in patients with chronic wounds. J Wound Care 21(2): 53-54. DOI: 10.12968/ jowc.2012.21.2.53.

28. Vukelić DJ, Jurić J (2017). Hydrocolloid dressing appliucation in the treatment of chronic wounds and relation to quality of life. Acta Clin Croat 56(3): 544-549 DOI: 10.20471/ acc.2017.56.03.22.

29. Vyhlídalová D, Zeleníková R, Pokorná A (2019). Využití škály PWAT při posuzování fotodokumentace nehojících se ran u seniorů v domácí zdravotní péči a hodnocení shody mezi hodnotiteli. Ošetrovatel'stvo 9(1): 15-22.

30. Zemanová J, Zoubková R (2012). Vybrané kapitoly z léčby bolesti. Ostravská univerzita v Ostravě, Ostrava, 61 p. 